\title{
Giant Complex Odontoma of the Anterior Mandible: Report of Case with Long Follow up
}

\author{
Pedro Henrique Rezende SPINI ${ }^{1,2}$ \\ Túlio Humberto SPINI ${ }^{2}$ \\ João Paulo Silva SERVATO ${ }^{1}$ \\ Paulo Rogério de FARIA ${ }^{1}$ \\ Sérgio Vitorino CARDOSO ${ }^{1}$ \\ Adriano Mota LOYOLA ${ }^{1}$ \\ ${ }^{1}$ Laboratory of Pathology, Dental School, UFU - Federal University of Uberlândia, Uberlândia, MG, Brazil \\ ${ }^{2}$ Dental Care Center for Special Needs Patients (NAPEO), Itumbiara, GO, Brazil
}

\begin{abstract}
This paper describes an exceptional case of an enormous complex odontoma affecting the mandibular symphysis of a 9-year-old boy. Because of its dimensions, the lesion produced cortical bone expansion, dental displacement and impactation, which are clinical signs very seldom described for odontomas. The lesion was surgically excised in a conservative way using an intraoral approach with local anesthesia. After 7 years of follow up, all teeth had erupted and the mandibular bone healed totally. Because of its radiographic mixed radiolucent and radiopaque appearance and its expansive growth, it is imperative to make the differential diagnosis of giant complex odontoma for other more aggressive mixed odontogenic tumors, such as ameloblastic fibro-odontoma, odotoameloblastoma and cystic calcified odontogenic tumor. Conservative approach appears to be indicated in the treatment of such lesions.
\end{abstract}

Key Words: odontogenic tumors, odontoma, complex odontoma, diagnosis, mandible.

\section{INTRODUCTION}

Odontomas are considered odontogenic hamartomas constituted by tooth-forming tissues laid down with variable degrees of organization and mineralization (1). Although they are considered the most common odontogenic lesion, no conclusive data on its frequency have been reported, since odontomas are included in different studies either as tumor or as hamartomas $(2,3)$.

Two types of odontomas have been recognized: compound and complex odontomas. The compound type, frequently diagnosed in the anterior maxilla, is characterized by the presence of which seems to be normal odontogenic tissue (dentin, enamel matrix, cementum, dental pulp) organized in a way that resembles normal teeth; the complex type shows an anarchic arrangement of the odontogenic tissue being more common in posterior mandible (4).

Odontomas may be diagnosed in patients of both genders. However, they are more frequent in women before the second decade of life. In general, they are asymptomatic and slow-growing, reaching no more than $3 \mathrm{~cm}$ in diameter (4). Large or giant odontomas have rarely been reported (5-7).

This paper describes an unusual case of a giant complex odontoma with $6 \mathrm{~cm}$ diameter in the mandibular symphysis of a young boy, which produced remarkable expansion and thinning of the cortical bone, as well as significant dental displacement and impaction. The lesion was totally removed through a conservative approach and all impacted teeth erupted normally over time.

\section{CASE REPORT}

A 9-year-old boy was referred to the dental clinic at the Dental Care Center for Special Needs Patients (NAPEO), Itumbiara, GO, Brazil, complaining of a slow growing and asymptomatic swelling in the mandibular 
symphysis with duration of 3 years. Medical history was not contributory. The intraoral examination revealed a bulging of the vestibular cortical bone with ill-defined limits encompassing the region from the permanent right first premolar to left one. The covering mucosa presented normal parameters of texture, color, brightness and consistency. Also, the primary mandibular left first incisor was missing.

Radiographs revealed an extensive mixed radiolucent and radiopaque lesion, with well-corticated limits, measuring approximately $6 \mathrm{~cm}$ in the major diameter. The radiopaque area was amorphous, circumscribed by a thin, somewhat irregular radiolucent halo. Further, the teeth from the permanent mandibular right canine to the permanent left one were impacted and dislodged from their normal position (Fig. 1). Based on this, the clinical hypotheses of giant complex odontoma and ameloblastic fibro-odontoma were raised.

An incisional biopsy was carried out and a histological diagnosis of complex odontoma was
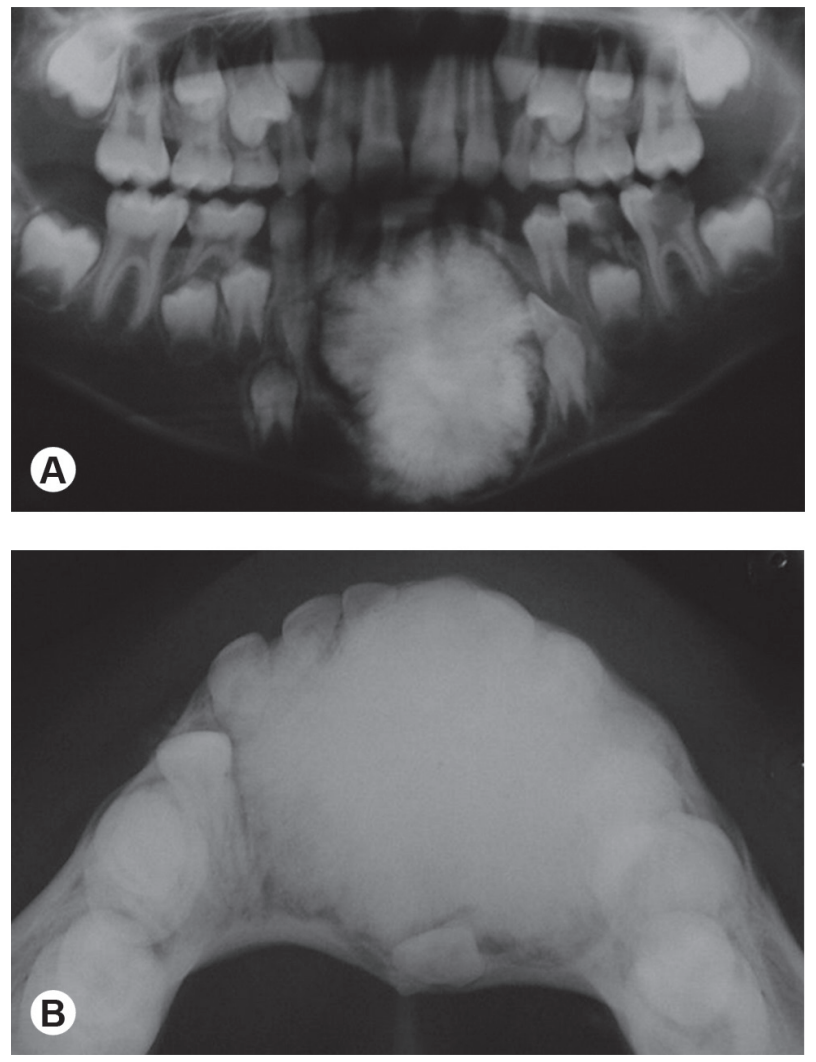

Figure 1. Panoramic (A) and occlusal (B) radiographs showing the dislodgment of several teeth from their normal position as well as the thin basal mandibular cortical bone associated with the lesion. suggested. Thus, a conservative exeresis of the lesion was made with an intraoral access in order to preserve the periosteum and mandibular basal cortical bone, which was quite thinned. During surgery, it was observed that the impacted teeth exhibited no apparent change in shape and size. Surgical approach was performed using a \#6 spherical drill and a \#704 tapered stem, and several blocks of odontoma were removed. The surgical cavity was totally smoothened and no complementary treatment was necessary. Mucoperiosteal flap was closed with interrupted stitches. Postoperative medication consisted of amoxicillin and analgesics for 7 days. Figure 2 shows radiographic postoperative appearance of the surgical area immediately after lesion resection.

Microscopic examination showed a grid of tubular dentin with holes containing enamel matrix and epithelium, dental pulp and, sometimes, cementum and a middle cellular conjunctive stroma. Periferically, a strip of mature connective tissue could occasionally be seen (Fig. 3).
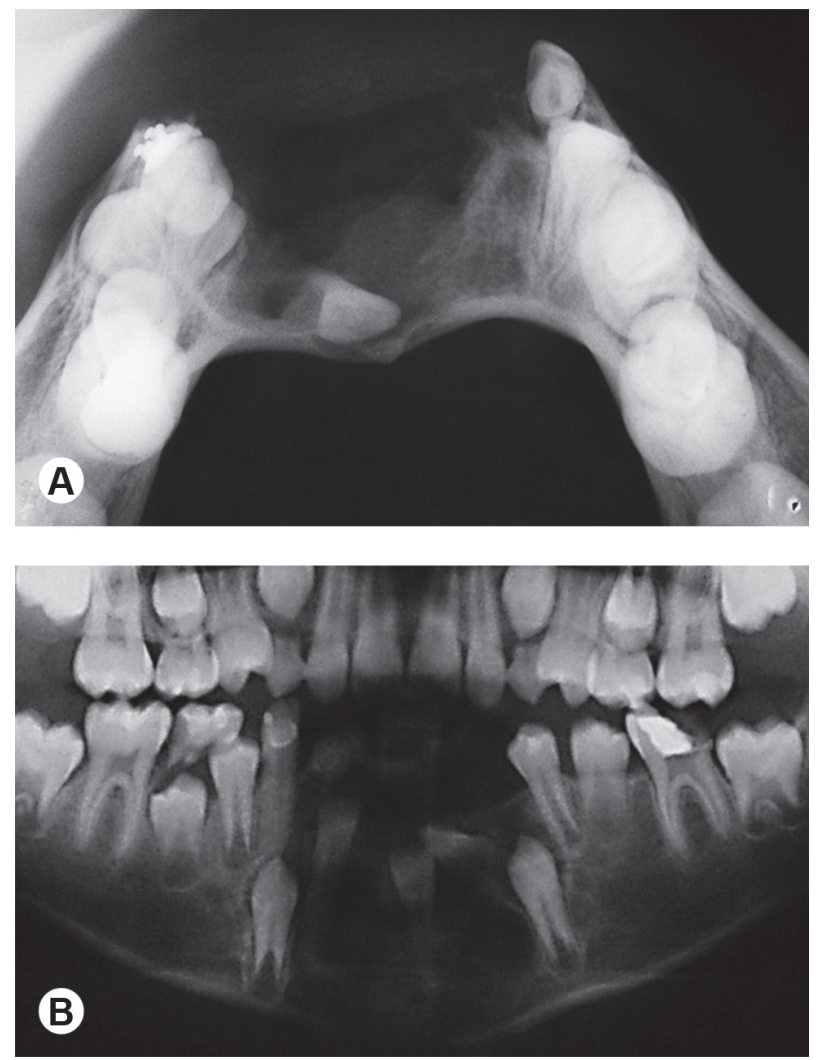

Figure 2. Occlusal radiograph and panoramic views showing two postoperative moments: postoperative appearance of the surgical area immediately after lesion resection (A) and postoperative appearance of the surgical area after 3 years of follow-up (B). 
A 7-year follow up showed that the bone healing was uneventful and no abnormality of symphysis development was observed. Further, all teeth attained normal development and eruption, but an inversion involving the mandibular right lateral incisor and canine was noticed (Fig. 4). The patient is currently under orthodontic treatment for correction of dental malposition.

\section{DISCUSSION}

According to the World Health Organization, odontomas are considered odontogenic hamartomas (1). In general, they grow asymptomatically and are detected incidentally by routine radiographs (during the investigation) to investigate possible causes of for delay in permanent tooth eruption and deciduous tooth retention. Most odontomas appear as small intraosseous lesions of calcified odontogenic tissues. Their growth is accomplished by gradual mineralization of the
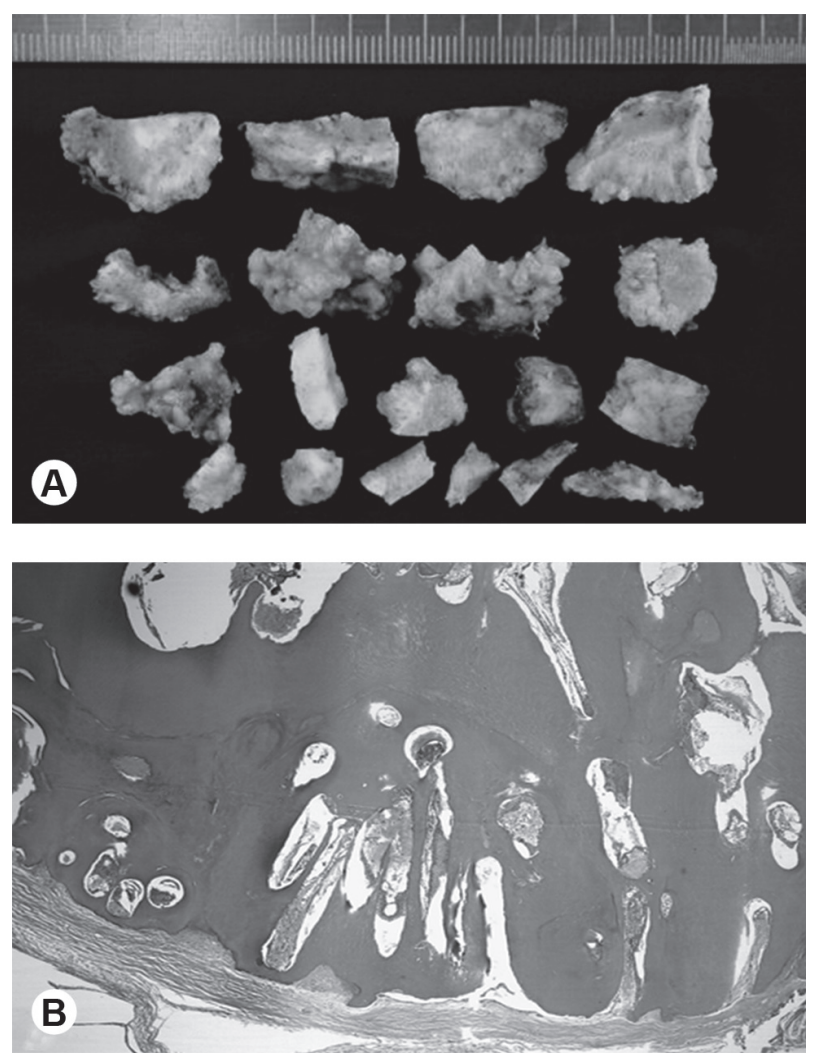

Figure 3. Gross aspect of the lesion (A). Histological findings (B) showing a mineralized lesion compost of enamel matrix, dentin and pulp tissue surrounding by a well-defined capsule of connective fibrous tissue. odontogenic tissue reaching a so-called mature stage when they are totally calcified. From that point, new episodes of growing are improbable. Because of this, odontomas are recognized as non-aggressive lesions with a limited growth potential $(4,8,9)$.

The present case is an exceptional example of a giant odontoma. Despite its known conceptually non-aggressive behavior, the lesion caused disturbance in the surrounding structures, such as impaction and displacement of the adjacent teeth, together with a remarkable expansion and thinning of the mandibular cortical bone (7).

Similar rare cases of lesions in jaws and maxillary sinuses have been reported (5-7). These facts could indicate that odontomas present an unpredictable growth rhythm, possibly reflecting a lesser differentiation of the odontogenic epithelium in the complex variant. And, the continuous growth of the hamartomatous odontogenic tissue before maturation, reproducing the invasive potential of the embrionary tissue, can, interfere with
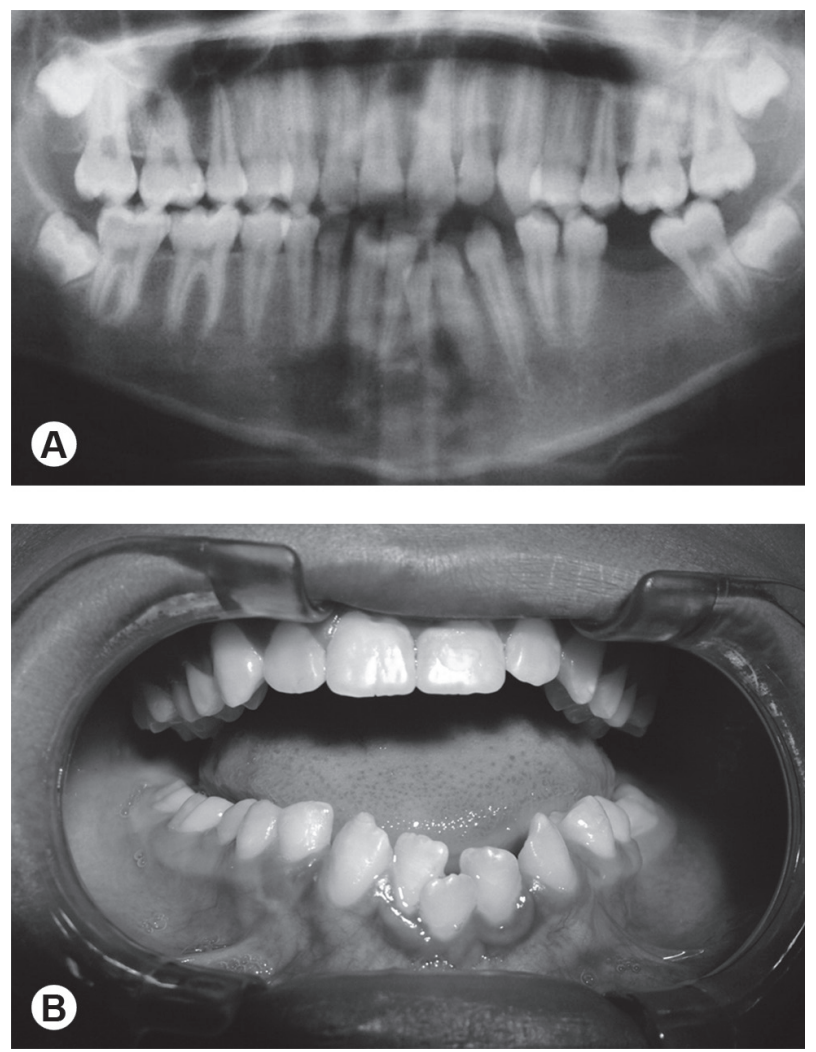

Figure 4. Radiographic (A) and intraoral clinical aspect (B) of the patient after 7 years of follow-up. All teeth had erupted. Note an inversion between the mandibular right lateral incisor and the canine. 
the local tissue homeostasis.

Pathological changes, such as impaction, malpositioning, aplasia, malformation and devitalization of adjacent teeth are associated with $70 \%$ of odontomas (10). Even more serious systemic consequences associated with odontoma growth have also been reported by Faria et al. (11), who described an unusual case of sellar compound odontoma that induced hypophysis disruption and, therefore, hypothyroidism, diabetes, and growth retardation in a 9-year-old child.

In general, because of the small dimension of the lesions and its uneventful biological behavior, a conservative surgical enucleation is recommended, and no cases of recurrence have been reported so far $(3,6)$. However, enucleation of large odontomas may affect adjacent bone and teeth (7). In the present case, the lesion was totally and carefully removed and no damage to the adjacent developing teeth or the thinned basal cortical bone was produced. After 7 years of follow up, only little alterations in bone anatomy and tooth positions could be observed, reflecting the good prognosis associated with this lesion.

Careful histological examination is always mandatory, especially when dealing with lesions of large dimensions, since they can be misdiagnosed with other odontogenic tumors that have a clear and more expansive growth potential or a more aggressive behavior such as ameloblastic fibro-odontoma, odontoameloblastoma and calcifying odontogenic cystic tumor $(1,12)$. Ameloblastic fibro-odontoma is considered a mixed odontogenic tumor composed of an odontoma-like mineralized tissue complex and a soft odontogenic tissue composed by a moderately cellular connective tissue matrix containing strands of odontogenic epithelium. It is commonly found in the posterior mandible in the first and second decades of life. The main differences in relation to the complex odontoma are its major content of soft odontogenic tissue and an evident growth potential. Cases of malignant transformation for ameloblastic fibro-odontoma have also been described $(8,12,13)$. Odontoameloblastoma is another very rare sort of mixed odontogenic tumor common affecting children and adolescents, whose aggressive growth is usually accompanied by bone expansion and root resorption. Histologically, it is characterized by the synchronic occurrence of complex or compound odontoma and ameloblastic epithelium with an ameloblastoma-like appearance, which was not observed in the present case (14). And finally, calcifying odontogenic cystic tumor is a cystic tumor usually diagnosed in the second and third decades of life that could be associated with complex or compound odontomas.

In conclusion, despite the large clinical manifestation, the present case appears to have similar behavior and prognosis of smaller odontomas. In this way, conservative surgery approach appears be indicated for such lesions.

\section{RESUMO}

Descrevemos um caso excepcional de um odontoma complexo gigante afetando a sínfise mandibular em um menino de nove anos de idade. Devido à sua dimensão esta lesão produziu expansão da cortical óssea, deslocamento dentário e impactação, sinais clínicos muito raramente descritos para odontomas. A lesão foi extirpada cirurgicamente de forma conservadora, utilizando uma abordagem intra-oral com anestesia local. Depois de sete anos de seguimento todos os dentes se encontram erupcionados e o osso mandibular totalmente curado. Devido à sua aparência radiográfica, mista radiolúcida e radiopaca, e seu crescimento expansivo, é imperativo fazer o diagnóstico diferencial de odontoma complexo gigante para outros tumores odontogênicos mistos mais agressivos, como o fibro-odontoma ameloblástico, odotoameloblastoma e tumor odontogênico cístico calcificante. Uma abordagem conservadora parece ser indicada no tratamento dessas lesões.

\section{ACKNOWLEDGEMENTS}

The authors are very grateful to the Fundação de Amparo a Pesquisa do Estado de Minas Gerais (FAPEMIG) and to the Conselho Nacional de Desenvolvimento Científico e Tecnológico (CNPq) for the financial support.

\section{REFERENCES}

1. Barnes L, Eveson JW, Reichart P, Sidransky D. Pathology and genetics of the head and neck tumors. World Health Organization Classification of Tumors. Lyon: IARC 2005.

2. Servato JP, de Souza PE, Horta MC, Ribeiro DC, de Aguiar MC, de Faria PR, et al.. Odontogenic tumors in children and adolescents: a collaborative study of 431 cases. Int J Oral Maxillofac Surg 2012;41:768-773.

3. Mortellaro C, Berrone M, Turatti G, Rimondini L, Del Prever $\mathrm{AB}$, Canavese $\mathrm{F}$, et al.. Odontogenic tumors in childhood: a retrospective study of 86 treated cases. Importance of a correct histopathologic diagnosis. J Craniofac Surg 2008;19:1173-1178.

4. Sánchez OH, Berrocal MIL, González JMM. Meta-analysis of the epidemiology and clinical manifestations of odontomas. Med Oral Path Oral Cir Bucal 2008;13:730-734.

5. Utumi ER, Cremonini CC, Pedron IG, Zambon CE, Cavalcanti MG, Ceccheti MM. Maxillary reconstruction with particulate bone graft and titanium mesh: a treatment option for large complex odontoma of the maxilla. J Dent Child 2011;78:124-128.

6. Ozeç I, Kiliç E, Yeler H, Goze F, Yeler D. Large complex odontoma associate with a primary tooth. Quintessence Int 2007;38:521-524.

7. Biocic J, Macan D, Brajdic D, Manojlovic S, Butorac-Rakvin L, Hat J. Large erupting complex odontoma in a dentigerous cyst 
removed by a piecemeal resection. Pediatr Dent 2010;32:255-259

8. Praetorius F. Odontogenic tumors. In Barnes L. Surgical Pathology of the Head and Neck. 3th ed. New York: Informa Healthcare; 2007:1202-1237.

9. Iatrou I, Vardas E, Theologie-Lygidakis N, Leventis M. A retrospective analysis of the characteristics, treatment and followup of 26 odontomas in Greek children. J Oral Sci 2010;52:439447.

10. Bodin I, Julin P, Thomsson M. Odontomas and their pathological sequels. Dentomaxillofac Radiol 1984;12:109-114.

11. Faria PR, Cardoso SV, Rocha A, Gomes DB, Castro SC, Loyola AM. Intracranial compound odontoma. J Cranio Maxillofac Surg 2009;37:367-379.
12. Soluk Tekkesin M, Pehlivan S, Olgac V, Aksakallı N, Alatlı C Clinical and histopathological investigation of odontomas: review of the literature and presentation of 160 cases. J Oral Maxillofac Surg 2011;70:1358-1361.

13. De Riu J, Meloni SM, Contini M, Tullio A. Ameloblasticfibroodontoma. Case report and review of the literature. J Cranio Maxillofac Surg 2009;38:141-144.

14. Dive A, Khandekar S, Bodhade A, Dhobley A Odontoameloblastoma. J Oral Maxillofac Pathol 2011;15:60-64.

Received November 29, 2011 Accepted April 23, 2012 